DOI: https://doi.org/10.15407/preislamic2021.02.113

UDC 94(355)

\title{
CANAL STELAE OF DARIUS I IN THE CONTEXT OF THE IMPERIAL POLICY OF THE ACHAEMENID STATE
}

\author{
I. O. Semenenko \\ Undergraduate Student \\ Charles University in Prague \\ 560/5, Ovocný trh, Prague 1, 116 36, Czech Republic \\ semenenko.illia99@gmail.com
}

The reign of Darius I was the heyday of the Achaemenid Empire. To successfully unite the entire Near East into a single state the king of Persia had to recognize local cultures and forms of political organization and to emphasize the fact that his subjects belonged to different ethnic groups, spoke different languages and had different ways of life. The integration of individual civilization centers into the general imperial trade and political system was an important goal to achieve. One of the most important activities in this concern was the (re-)digging of a canal by Darius I, which connected the Nile with the Red Sea. This canal successfully illustrates Persian policy in the subordinate territories. It ran through the dry wadis of the Eastern Desert and the Isthmus of Suez, where, long before the founding of the Achaemenid state, several different waterways existed, created by the pharaohs of the $26^{\text {th }}, 19^{\text {th }}$ and possibly $9^{\text {th }}$ Dynasties. Acting within the framework of local customs and using the experience of successfully functioning administration system of Egypt, Darius I, with the use of enormous resources of his empire, for the first time in history created the phenomenon that significantly changed the map of the Red Sea trade routes for centuries. This article deals with several bilingual stelae which were installed on the promontories along the canal. Their cuneiform and hieroglyphic inscriptions glorify the construction of the canal by Darius and transmit his imperial titles in Ancient Egyptian, Old Persian, Babylonian and Elamite. The study of the motifs and texts depicted on the stelae sheds a new light on the process of (re-)digging of the canal and on the imperial policy of the Achaemenid state in the region. neiform

Keywords: Achaemenid Empire, Darius I, Canal of the Pharaohs, Red Sea, Old Persian, cu-

\section{Introduction}

Before proceeding to the discussion itself, it is necessary to introduce two issues, both of which are of high importance for the present discussion. First of all, the author assumes that the environment and the landscape surrounding us shape those who dwell in it. The history of human development is a constant search for answers to the challenges posed to humanity by nature. Natural phenomena or elements of natural landscape had an extremely strong influence on the formation of early agricultural civilizations. This is particularly true for Egypt ${ }^{1}$, which is (excluding the Delta and several remote desert oases), in fact, a thin stretch of fertile Nile valley sandwiched between the Eastern and Western Deserts (Herod., Hist., II.5) ${ }^{2}$. Actually, the Nile, being a dominant feature of Egyptian natural landscape, had such a big impact on the country, that Herodotus, when visiting it, noticed that the big part of the land was brought to Egyptians by the river ${ }^{3}$.

${ }^{1}$ For the general discussion see: [Manning 2018]. For particular cases of humans dealing with challenges posed by natural environment see for example [Welsby 2021, 309-326] or [Malleson 2021].

${ }^{2}$ For the overall discussion on Egyptian geography see: [Baines \& Malek 2000].

${ }^{3}$ For the discussion on this paragraph see: [Griffiths 1966, 57-61]. 
Accordingly, it was local riverine and desert landscape that was a primeval factor determining Egyptian culture, architecture, mentality and state policy as well.

However, this process is never one-sided. It is important to note, that environment and landscape is always equally shaped by people inhabiting them. From the emergence of the earliest agriculture in the Nile Valley ${ }^{4}$ its dwellers did their best to improve its natural conditions. Later on, with the growth of population, they started to drain swamps and build dams. They dug channels ${ }^{5}$ and created artificial basins to increase the cultivated area $^{6}$, which allowed the early society to accumulate resources so indispensable for the early state to emerge. In other words, human activity was as important as the environmental factor in shaping the course of events.

The second issue which must be considered here is the possible (un-)visibility of the two factors outlined above for us, the modern scholars. Sometimes it is very difficult, or even impossible to trace and reconstruct without any written evidence the development of one particular landscape with considerable degree of certainty, this development being either of completely natural, artificial (anthropogenic), or combined character. For example, the reconstruction of the exact flow of the Nile Delta branches ${ }^{7}$ during such a distant period of Egyptian history as the Old Kingdom will be always obscure due to accumulation of the river alluvia, the factor which hides traces of the earlier river beds in the region. However, knowledge of their locations would be very important for scientists working not only in the field of paleogeography. These data would be of immense value for the scholars studying the Lower Egyptian administration patterns as well, for borders between the districts there, the so-called nomes, were often drawn following the Nile branches $^{8}$.

Fortunately, such an unclearness of data is not always observed. For some elements of landscape, both natural and man-made, we dispose of the written sources that describe them. The present article offers a discussion on exactly such texts - the so-called "Canal stelae" of Darius I. Through the study of their texts we can find answers on many important questions concerning political development of the region, its interconnections with other areas, even the most distant ones, trade patterns and also peculiar details on the canal itself. Installed along the canal connecting the Nile and the Red Sea, these monuments of the $27^{\text {th }}$ Egyptian Dynasty shed light on the process of (re-)digging of the canal in the Persian period and on the imperial policy of the Achaemenid Empire in the region.

These monuments did not exist in a void. They were anchored in the physical and cultural landscape of the area to the north of the Red Sea, which is one of the oldest areas of intercultural contact in the world ${ }^{9}$. Its narrowest part, known as the Isthmus of Suez, separates the Red Sea from the Mediterranean world, but also connects Africa with the Near East. This geographical factor shaped the life and development of the Isthmus of

${ }^{4}$ For the first Neolithic agricultural societies in Egypt see: [Hendrickx, Vermeersch 2003, 16-40].

${ }^{5}$ See the Macehead of the King Scorpion with the canal opening ceremony.

${ }^{6}$ For the irrigation in the Nile valley see: [Butzer 2020, 99-124].

${ }^{7}$ For the development patterns of Nile Delta, its waterways and landscape see for example: [Stanley \& Warne 1993, 628-634], or [Wilson 2012, 95-117].

${ }^{8}$ For the Lower Egyptian administrative system, see: [Martinet 2017, 219-236].

${ }^{9}$ Stone tools dating back to the Middle Paleolithic recently discovered near Dimona in the Negev desert are the perfect evidence for the existence of early Afro-Asian contacts through the Isthmus of Suez, since they were shaped using the so-called Nubian Levallois, a technique originating in Africa. 
Suez and its adjacent regions of Wadi Tumilat and Eastern Delta during almost every historical (or prehistorical) era. However, the landscape of this region, being the borderland between Egypt and the Near East, and, in wider perspective, between Africa and Asia, was also permanently modified according to the needs and ambitions of rulers dominating over it. The "Canal stelae" of Darius the Great ${ }^{10}$, a ruler of the Iron Age Persian Achaemenid dynasty (550-486 BC), bear a unique testimony of the Egyptian imperial policy of this overlord, whose seat was very remote from the region in question. The stelae refer to a unique era of multiculturalism ${ }^{11}$ and at the same time centralization, which created possibilities for unprecedented interconnections for the people of the Near East. The unusual and unique syncretism of Egyptian and Near Eastern elements in their depictions is very thought-provoking. The present author is deeply convinced that the study of these inscriptions is very beneficial not only for understanding the essence of this policy, but also for unveiling the contacts between Ancient Egypt and wider Iron Age world. Accordingly, the aim of the present paper is to demonstrate, using the fragmentary hieroglyphic inscriptions on the three stelae of Darius I - those from Tell el-Maskhuta, Shaluf (this monument is also sometimes referred to as the Kabrit stele) and Koubri (or Suez stele), the peculiar features of the imperial policy of Darius I, and also to make some remarks on the possible implications of these texts for the study of the so-called Canal of the Pharaohs. The main source used for the study of the Ancient Egyptian texts found on the stelae is an important edition of hieroglyphic inscriptions from the Persian period by Georges Posener - La première domination perse en Égypte: recueil d'inscriptions hiéroglyphiques (1936). The author provides an insightful analysis of all the hieroglyphic fragments of the Canal Stelae of Darius I, a bibliography and suggests readings for some important passages. This book, although being almost a century old, still remains the most complete edition of the hieroglyphic inscriptions on these monuments. Editions of single monuments were used as a supplement to this major work [Maspero 1886, 1-7; Daressy 1889, 160-171; Golénischeff 1890, 99-109; Klotz 2015, 267-280; Wolze 2019, 1275-1320].

The monuments also bear cuneiform texts. These are much shorter, so that their trilingual inscriptions ${ }^{12}$ cover the same space on the other side of the stelae as their hieroglyphic counterparts. They are largely outside the scope of the present paper due to the fact that they do not contain much information besides the dedicatory passage to Auramazda, "who created yonder heaven, who created this earth, who created man, who created happiness for man, who made Darius king" [Kuhrt 2007, 485], and a short proclamation of Darius I. However, they also transmit his imperial titles. This laconic statement of power shows a meaningful ideological substructure under the whole canal enterprise and puts an important emphasis on the ethnicity of the king. Unwilling to delve into the tradition of the Near Eastern and, in particular, Persian royal inscriptions, the

\footnotetext{
${ }^{10}$ A concise summary of the reign of Darius I and his immediate predecessors with further reading can be found in [Sancisi-Weerdenburg 1995, 1035-1050]. For the early reign of this king see: [Vavroušek 2001, 31-46].

${ }^{11}$ This is evidenced by the fact that the stelae are in fact quadrilingual, comprising inscriptions in Egyptian hieroglyphic script on the one side and cuneiform inscriptions in Old Persian, Babylonian and Elamite on other side.

12 The cuneiform texts are written in the Old Persian, Elamite and Babylonian languages, see: [Posener 1936, 49].
} 
present author will briefly refer to this issue later. For the needs of the present paper the English [Kuhrt 2007, 485-486 with references] and German [Weißbach 1911, 102-105] editions of cuneiform texts were used.

Now, having thus indicated several important introductory points, let us ignore for the moment the textual analysis of the monuments and instead turn to their brief description.

\section{The Canal Stelae - A Description}

The so-called "Canal stelae" are the monuments erected by order of the king Darius I along the route of a navigable canal which connected the Nile with the Red Sea. This artificial body of water became a matter of interest for classic authors ${ }^{13}$ and a subject of a lively discussion in the modern Egyptological literature ${ }^{14}$. The stelae were erected on the elevated places, sometimes on podiums ${ }^{15}$, along the canal, so that they would be visible for vessels passing it. The canal ran through the dry wadis of the Eastern Desert and the Isthmus of Suez, especially the one known as Wadi Tumilat. The archaeological survey of numerous wadi sites has shown that it was first extensively inhabited in the Second Intermediate period, or even in the late $12^{\text {th }}$ Dynasty [Ryholt 1997, 103], way before any Persian activity in the region.

At the moment, at least four monuments are known ${ }^{16}$. They are all large stelae hewn of granite. For the sake of completeness of data it would be useful to determine their geographic location here. The first stela of the four Canal inscriptions of Darius I was erected near the village of Tell el-Maskhutah in the eastern part of the Wadi Tumilat southeast of Cairo $^{17}$. The second stela once stood north of Ismailia on the present-day Suez Canal in a locality called Serapeum ${ }^{18}$. The third could be seen south of the Great Bitter Lake near the village of Chaluf [Posener 1936, 63-81] and the last one in Koubri [Posener 1936, $81-87]^{19}$, about $6 \mathrm{~km}$ north of Suez, apparently near the Suez end of the canal. The reader should not be confused by the fact that only the three stelae were mentioned earlier as comprising the textual basis for the present paper. The stele of Serapeum, recovered in 1884 by Clermont-Ganneau, was found very fragmented. Posener notes ${ }^{20}$ that two years later its fragments were transferred to Louvre and subsequently disappeared there. It is for this reason that they will remain outside the scope of the present discussion. These 23

\footnotetext{
${ }^{13}$ Among others, it was mentioned by Herodotus, Strabo and Plinius the Elder. For the complete list of mentions of the Canal in antiquity see: [Redmount 1995, 127-135] with references.

${ }^{14}$ See inter alia [Cooper 2009, 195-209; Redmount 1995, 127-135] and especially [Tuplin 1991, 237-283].

${ }^{15}$ So for example the stele from Shaluf, see: [Clédat 1916, 201-203].

${ }^{16}$ Thus [Root 1979, 61]. Another opinion is that of Sir William Flinders Petrie [Petrie 1918, 366], where the five stelae are mentioned. In fact, it is not possible to speak with complete certainty about the exact number of stelae due to the fragmentary condition of the many fragments found, which makes it a bit difficult to ascribe them to one particular monument. The present paper names the four stelae according to major point of view accepted in the literature.

${ }^{17}$ It is published in [Posener 1936, 50-63] and received a conventional number 8 in this publication.

${ }^{18}$ For the fate of this monument consisting of badly damaged fragments see: [Posener 1936, 48, fn. 3].

${ }^{19}$ See also: [Clédat 1916, 224-228].

${ }^{20}$ See: fn. 18.
} 
or 25 pieces of granite are probably still in the Louvre, resting somewhere in its vast repositories since the end of the last century. Hopefully, they will be found sometimes in the near future and hence will be available for scholars.

The other two stelae mentioned, those of Chaluf and Koubri, are unfortunately a bit fragmented. However, their partial remains have been successfully recovered and can still be examined, preserving their texts for the scholars. In order not to completely repeat what can be found in earlier publications, it would be best to note briefly that the first inscribed fragments of the stela of Chaluf were found by Charles de Lesseps, son of Ferdinand de Lesseps, in 1886 during the construction of the Suez Canal. Several smaller fragments unearthed were lost, but larger slabs were fortunately reburied in the sand. They were rediscovered in 1911-1912 by Jean Clédat, who, together with several cuneiform fragments newly found, sent them in Ismailia. There they were later reassembled ${ }^{21}$. One fragment of the stele featuring a part of a wing of the winged solar disc, as well as several cuneiform signs, was donated to the Louvre in 1892 by Victor Chartrey, an agent of the Universal Company of the Maritime Canal of Suez. The stele of Koubri is mentioned in a letter from Charles de Lesseps to Auguste Mariette of the $8^{\text {th }}$ April 1866 [Maspero 1886,3$]$, which proves that it was known as early as the mid- $19^{\text {th }}$ century. However, the two main fragments of the monument, a hieroglyphic and a cuneiform (Old Persian version) one, were discovered by Clédat during the same archaeological campaign of 1911-1912. Hieroglyphic fragment represents a third of the original width of the stele fortunately preserving the whole length. The cuneiform fragment is much smaller ${ }^{22}$. Both stelae were originally more than three meters high and were hewn of a fine pink granite, called by monsieur Charles de Lesseps "le granit de Syène" [Maspero 1886, 2].

Now we should turn to the best preserved one of the Canal Stelae - the stele from Tell el-Maskhutah. It is kept in the Cairo Museum (Cairo 1182 or J.E. 48855). Its fragments were first found by M. Jaillon, another employee of the Universal Company of the Canal of Suez, in 1864 and subsequently reburied. These blocks of pink granite were rediscovered more than two decades later by Vladimir Golenisheff and in 1907 ended up in Cairo Museum. The whole monument in its present state consists of seven fragments which comprise almost three quarters of the stele when assembled together. There is also the eighth hieroglyphic fragment position of which is uncertain ${ }^{23}$, and some fragments bearing cuneiform text from the opposite side of the stele. The monument displays a quite well preserved hieroglyphic text and an almost complete lunette placed below the winged solar disc. It must be noted here that, as it seems, almost all the stelae shared the same or almost the same decoration program with its two versions - hieroglyphic and cuneiform, on opposite sides, which differ significantly among each other but probably had almost no discrepancies among the single monument ${ }^{24}$. When complete, they formed together a perfect example of the imperial ideology expressed by the means of image. Unfortunately,

${ }^{21}$ See: [Posener 1936, 63, fn. 1].

${ }^{22}$ See: [Clédat 1916, 225].

${ }^{23}$ See: [Golénischeff 1890, 99-109] and also [Posener 1936, 58].

${ }^{24}$ Besides the stele of Tell el-Maskhuta, the only monument which has a considerably preserved hieroglyphic version of the lunette is the stele of Chaluf. Despite being heavily damaged, the lunette seems to be the almost exact copy of that on the stele of Tell el-Maskhuta. The lunette of the stele of Koubri is lost, but, keeping in mind the overall similarity of the monuments there is no reason to assume significant differences in the decoration of its hieroglyphic side either. 
all the monuments are incompletely preserved, so that one stele lacks some parts preserved on the other. Thus, the Tell el-Maskhuta stele does not dispose its cuneiform version, which was, according to Golenisheff, inscribed on a separate monument [Posener 1936, 49, fn. 3], but has a perfectly preserved hieroglyphic version. On the contrary, the stela of Chaluf is badly damaged on its hieroglyphic side but has a quite well preserved cuneiform side, enabling us to compare the two versions of the lunette.

The hieroglyphic side displays traditional Egyptian imagery referring to power and prestige. Here, under the winged sun disk, two fecundity figures are depicted, symbolizing richness and abundance. They are granting the reigning king, i.e. Darius I, with life, might and health. Here a traditional formula dj. $n=j n=k^{25}$ is used, which is an indication of status. The fecundity figures are knitting together the heraldic plants of Upper and Lower Egypt - lotus and papyrus, which are surmounted by the cartouche of Darius I. This is the so-called "smAtAwj motif", a symbolic union of the two parts of the Nile valley - the Upper and Lower Egypt. It is deeply rooted in the Egyptian royal iconography. We may assume that in the context of these very stelae it had another peculiar meaning. The fecundity figures might here represent the Nile and the Red Sea being connected by the canal made by Darius I. In this case it is Darius I who becomes a principal actor in the scene. He is symbolically "depicted" in the guise of his cartouche and acts as an overlord who brings riches to Egypt by the means of improving its physical landscape and through the interaction with Egyptian religious (or cultural) entities. In fact, this is a traditional role of the pharaoh [Bonhême 2001, 238-245]. Such is an emphasis of the Egyptian version of the lunette, reflecting the Persian imperial policy in the Nile Valley. The depiction below the lunette of the twenty-four provinces subjugated by Darius I makes an additional emphasis on the imperial, multicultural and international character of the Persian Empire. The toponyms are placed inside the cartouches arranged geographically. They are surmounted by figures of the bound captives in the national garments of their lands. This only enhances the abovementioned impression.

The cuneiform version, which is found the most complete on the the stela of Chaluf, is slightly different, despite having a similar composition. It is still surmounted by the winged sun disk, which is partly covered by the cuneiform inscription. The lunette below still depicts the "SmAtAwj motif", but the fecundity figures are replaced by the two symmetrical figures of the Persian king performing the same action of knitting together the two heraldic plants. Probably it is not a coincidence that the predecessor of Darius I, Cambyses II (530-522 BC) bore the same-sounding Egyptian Horus name rmAtAwj. Thus we may interpret the scene by stating that only Darius I and his predecessor Cambyses II who conquered Egypt are able to connect the Nile valley and the Persian Empire together. The scene in the whole proclaims that it is solely the king who keeps the empire away from disintegration and thus protects its people from chaos. The king is not the main, but the sole actor here. Above him is only the sun disc, which may be conventionally understood as Auramazda - the god who endowed Darius I with power ${ }^{26}$. There is also a cartouche on the top of the plants, and we must note that the king's name in it is not written in the hieroglyphs, but in the cuneiform script. This cuneiform cartouche perfectly demonstrates the essence of the stelae as a cultural product of the multicultural Achaemenid

\footnotetext{
25 "I have given to you". See: [Baines 1985, 137-138].

${ }^{26}$ See the cuneiform text itself in: [Kuhrt 2007, 485].
} 
Canal Stelae of Darius I in the Context of the Imperial Policy of the Achaemenid state

Empire, whose policy lied in the combination of seemingly incompatible cultural and political traditions of the distant regions of the Near East into the one vast empire.

Having thus compared the pictorial programs of the two sides of the stelae in the context of the imperial policy of the Persian king, we now proceed to a brief analysis of the texts carved on the steles.

\section{The Canal Inscriptions - A Discussion}

The inscriptions on the three stelae aim to introduce on the monument a real event with the sacral connotations. Both the hieroglyphic and cuneiform versions of the text are opened by the connection of a king to a god, thus strongly indicating the sacral aspect of the Persian imperial kingship. However, there are several crucial distinctions. In the hieroglyphic version found on the stele from Tell el-Maskhuta Darius I is said to be the son of the goddess Neith. Neith was one of the most important goddesses of the Late Period, the tutelary goddess of Sais - the capital of the preceding $26^{\text {th }}$ Dynasty, and mother of $\mathrm{Re}^{27}$. Calling himself the image of Re and making reference to Neith was a politicoreligious statement of power connecting the Persian ruler to the earlier native Egyptian dynasty and legitimizing him through this connection. However, Darius I also bear his Persian dynastic name - the Achaemenid ${ }^{28}$. Such was a message transmitted by the hieroglyphic version of the stelae to the indigenous Egyptian population. Darius I is depicted as a foreign ruler. However, he is also a fully legitimate Egyptian pharaoh. This message is supported by his other projects in Egypt ${ }^{29}$.

The three cuneiform texts have another agenda. As was mentioned earlier, they consist of a eulogy for Auramazda, with Darius I introducing himself as a Great King of Persia and of his proclamation rendered in the first person. The king emphasizes that he is a conqueror who subdued Egypt by force. The benevolence of Neith, who is not even mentioned in the cuneiform inscriptions, towards the King of Persia does not matter outside the Nile Valley. It is the King's will that matters, as well as blessing of the great Auramazda. It is only the King who is mighty enough to make a significant impact on the Egyptian landscape - an act that was beyond the power of even his predecessor pharaohs $^{30}$. The cuneiform version mentions the building of a canal - the very raison d'être of the stelae, through the prism of execution of the King's orders, thus endowing him with the highest authority ${ }^{31}$. Unlike the cuneiform text, the hieroglyphic version, even in its present state, is relatively rich in details. For several scholars it seemed to correspond to the so-called Egyptian "Königsnovelle"32. It is executed in the third person, which is traditional for Egyptian royal building inscriptions. The Egyptian $s D m . n=f$ form is often used in the passages relating to the deeds and orders of the King, depicting an already performed action. The reliance of the King on the local officials [Posener 1936, 59, 71 and 76] from Egypt is in the complete agreement with the main principle of Persian

\footnotetext{
${ }^{27}$ See: [Stevens 2020, 185-194], and [Scheil 1982, 392-394].

${ }^{28}$ Also: [Posener 1936, 59, 71 and 76].

${ }^{29}$ See: [Stevens 2020, 185-194], [Lloyd 2007, 99-115] and [Razmjou 2002, 81-104].

${ }^{30}$ After Herodotus, the king Necho II from the $26^{\text {th }}$ Dynasty also attempted to dig the canal but was unable to finish the project. See: Herod., Hist., II.158-159.

${ }^{31}$ The real reasons behind the whole canal-digging enterprise of Darius are left out of discussion in this paper owing to the orientation of the discussion. For some ideas on this matter see for example [Klotz 2015, 267-280, Redmount 1995, 127-135] and [Tuplin 1991, 237-283].

${ }^{32}$ For the definition and possible origin of this literary device see: [Spalinger 2011, 351-374].
} 
imperial policy of preserving the local administrative patterns and using them for the imperial advantage, and is also confirmed by other texts ${ }^{33}$. The re-digging of the canal, an action "the like of which has not occurred before" ${ }^{34}$, is remarkably similar to traditional statements made by the native pharaohs. Thus the stelae installed on the hillocks along the route of the canal helped to create an attractive image of Darius I among all his subjects, whether indigenous to the area or not, and preserved it for eternity.

Interestingly, a lot of research has been carried out on the topic where geographically the steles with the texts inscribed on them were originally located. Instead, the current author asked himself not where, but when they were erected. It is important to note that the three preserved variants of the hieroglyphic version differ in several aspects. Naturally, the differences are somewhat obscured by the fragmentary state of the stelae of Shaluf and Koubri, but we are still able to discern general trends. The inscription from the stele of Tell el-Maskhuta pays more attention to the imperial titles of Darius I and to the events preceding the building of the canal. It mentions epithets traditional for the Egyptian royal ideology, for example, the "image of $\mathrm{Re}{ }^{35}$, and also demonstrates the phraseology traditional for the Egyptian kingship. It also contains, however, a loan from the Persian royal phraseology - the epithet "King of Kings" ${ }^{36}$. The canal itself is mentioned in the very end of the inscription, specifying that there were 8 iteru without water. Instead the council is emphasized after which Darius gives his orders. The overall impression is that of a preliminary inscription created in the very beginning of the works on the re-digging the canal. On the contrary, the stele from Shaluf preserves only seven incomplete rows dedicated to the titles and epithets of the king and makes an emphasis on the process of re-digging instead, with the Egyptian inspectors and princes involved. The ships dispatched to Persia mentioned twice in the inscription may be a rhetoric figure, for there are serious objections for the possibility of circum-Arabian navigation as early as in the $6^{\text {th }}-5^{\text {th }}$ centuries $\mathrm{BC}^{37}$. Finally, there is a passage mentioning the king's order to erect commemorative stelae along the canal and their subsequent installation. The third stele at our disposal, that of Koubri, is very fragmented, but it seems to more or less closely follow the textual patterns established on the stele of Shaluf [Posener 1936, 85-87]. From this it is tempting to assume that the stelae were erected in succession, in connection with the progress in re-digging the canal. It may be important that the classical authors, the first one being Herodotus (Herod., Hist., II.158ff), defined the canal of Darius as the one running from the Nile little above Bubastis by the Arabian town of Patumus ${ }^{38}$ and issuing later into the Red Sea. This may reflect an actual direction of the earth works during the canal re-digging. In this case the first monument erected was the stele from Tell el-Maskhuta, followed by the stele of Serapeum ${ }^{39}$, then by the one of Shaluf, and finally by that of Koubri. A possible objection to this theory is that all four monuments appear to have been hewn from the same material - the fine pink granite ${ }^{40}$, and though have probably been recovered from the quarry

\footnotetext{
${ }^{33}$ See: [Lichtheim 1980, 36-41; Stevens 2020, 185-194] and [Lloyd 2007, 99-115].

${ }^{34} \mathrm{nn}$ sp Xpr mitt, line 22 on the stela from Chaluf, see: [Posener 1936, 76].

35 Twt $n$ Ra, line 1 on the stela from Tell el-Maskhutah, see: [Posener 1936, 55, 58]

${ }^{36}$ pAwr n nAwrw, line 4 on the stela from Tell el-Maskhutah, see: [Posener 1936, 55, 59].

${ }^{37}$ Thus [Tuplin 1991, 270ff].

${ }^{38}$ The Greek name of Tell el-Maskhuta deriving from the Egyptian Pr-Itm.

${ }^{39}$ Now lost in the Louvre, see part 2.

${ }^{40}$ See: [Posener 1936, 48].
} 
Canal Stelae of Darius I in the Context of the Imperial Policy of the Achaemenid state

all in the same time. However, this statement in fact does not pose any threat for the theory. It is possible that the four stelae were indeed hewn all in the same time, but were subsequently inscribed and installed on their respective places as the works on the canal progressed. Unfortunately, this theory will remain difficult to prove, at least until the fragments of the Serapeum stela would be found again in the Louvre and studied properly.

With all the above in mind, it becomes evident that the four monumental stelae of Darius I installed on the promontories along the canal occupy a prominent place in the study of the policy of this king towards Egypt. The differences between the hieroglyphic and the cuneiform versions of their inscriptions, as well as between their decoration programs unveil few important details not only on the route of the canal, its construction process and the accompanying information as outlined above. The hieroglyphic texts, resembling the so-called "Königsnovelle", show a specific aspect of a King's life that encompassed his relationship to mankind and history ${ }^{41}$. They help us to better understand the broader context of the imperial policy of the multicultural Persian Empire on the peak of its glory, creating the new inter-regional communications and connecting the distant cultures without sacrificing their uniqueness.

\section{REFERENCES}

Baines J. (1985), Fecundity Figures: Egyptian personification and iconology of a genre, Aris \& Phillips, Warminster.

Baines J. and Malek J. (2000), Cultural Atlas of Ancient Egypt, Checkmark Books, New York.

Butzer K. W. (2020), "Landscapes and environmental history of the Nile valley: a critical review and prospectus", in I. Shaw and E. Bloxam (eds), The Oxford handbook of Egyptology, Oxford University Press, Oxford, pp. 99-124.

Cameron G. G. (1943), "Darius, Egypt, and the 'Lands Beyond the Sea'", Journal of Near Eastern Studies, Vol. 2, No. 4, pp. 307-13.

Clédat J. (1916), "Notes sur l'isthme de Suez [§ I-VII, avec 1 planche]", Bulletin de l'Institut Français d'Archéologie Orientale, T. 16, pp. 201-28.

Cooper J. P. (2009), "Egypt's Nile-Red Sea Canals: Chronology, Location, Seasonality and Function", in L. Blue, J. Cooper, R. Thomas, and J. Whitewright (eds), Connected Hinterlands: Proceedings of Red Sea Project IV, held at the University of Southampton, September 2008, British Archaeological Reports International Series, 2052, Archaeopress, Oxford, pp. 195-209.

Daressy G. (1889), "Révision des Textes de la Stèle de Chalouf”, Recueil de Travaux Relatifs à la Philologie et à l'Archeologie Égyptiennes et Assyriennes: Pour Servir de Bulletin à la Mission Française du Caire, T. 11, pp. 160-71.

Golénischeff W. (1890), "Stèle de Darius aux Environs de Tell El-Maskhoutah", Recueil de Travaux Relatifs à la Philologie et à l'Archeologie Égyptiennes et Assyriennes: Pour Servir de Bulletin à la Mission Française du Caire, T. 13, pp. 99-109.

Gozzoli R. B. (2006), The Writing of History in Ancient Egypt during the First Millennium BC (ca. 1070-180 BC). Trends and Perspectives, GHP Egyptology, 5, Golden House Publications, London.

Griffiths G. J. (1966), "Hecataeus and Herodotus on 'A Gift of the River' ", Journal of Near Eastern Studies, Vol. 25, No. 1, pp. 57-61.

\footnotetext{
${ }^{41}$ Quoted from: [Loprieno 1996, 278].
} 
Head R. (2010), “Assyria at Bisitun and the Universal Kingship of Darius I of Persia", in H. D. Baker, E. Robson, and G. Zólyomi (eds), Your Praise is Sweet. A Memorial Volume for Jeremy Black from Students, Colleagues and Friends, Oxbow Books, Oxford, pp. 117-24.

Hendrickx S. and Vermeersch P. (2003), "Prehistory: From the Palaeolithic to the Badarian Culture (c. 700,000-4000 BC)", in I. Shaw (ed.), The Oxford History of Ancient Egypt, Oxford University Press, Oxford, pp. 16-40.

Holladay J. S. (2001), "Pithom", in D. B. Redford (ed.), The Oxford Encyclopedia of Ancient Egypt, Vol. III, Oxford University Press, Oxford, pp. 50-3.

Kent R. G. (1943), "Old Persian Texts", Journal of Near Eastern Studies, Vol. 2, No. 4, pp. 302-16.

Klotz D. (2015), "Darius I and the Sabaeans: Ancient Partners in Red Sea Navigation", Journal of Near Eastern Studies, Vol. 74, No. 2, pp. 267-80.

Kuhrt A. (2007), The Persian Empire. A Corpus of Sources from the Achaemenid Period, Routledge, London.

Lloyd A. B. (1977), "Necho and the Red Sea: some considerations", The Journal of Egyptian Archaeology, Vol. 63, pp. 142-55.

Lloyd A. B. (2007), "Darius I in Egypt: Suez and Hibis", in Chr. Tuplin (ed.), Persian Responses. Political and Cultural Interaction within the Achaemenid Empire, Classical Press of Wales, Swansea, pp. 99-115.

Loprieno A. (1996), "The 'King's Novel'”, in A. Loprieno (ed.), Ancient Egyptian Literature, History and Forms, Brill, Leiden, New York, and Cologne, pp. 277-95.

Malleson C. (2021), "Agriculture and environment in the Wadi Tumilat, Egypt, $2^{\text {nd }}$ $1^{\text {st }}$ millennium BC", Journal of Archaeological Science: Reports, 37.

Manning J. G. (2018), The Open Sea: The Economic Life of the Ancient Mediterranean World from the Iron Age to the Rise of Rome, Princeton University Press, Princeton.

Martinet É. (2017), 'L'administration des nomes de Basse-Égypte sous l'Ancien Empire", in M. Bárta et al. (eds), Abusir and Saqqara in the year 2015, Faculty of Arts, Charles University, Prague, pp. 219-36.

Maspero G. (1886), "Pièces Relatives à la Découverte du Monument de Chalouf", Recueil de Travaux Relatifs à la Philologie et à l'Archeologie Égyptiennes et Assyriennes: Pour Servir de Bulletin à la Mission Française Du Caire, T. 7, pp. 1-7.

Menant J. (1887), "La stéle de Chalouf", Recueil de Travaux Relatifs à la Philologie et à l'Archeologie Égyptiennes et Assyriennes: Pour Servir de Bulletin à la Mission Française Du Caire, T. 9, pp. 131-57.

Nallino C. A. (1930), "L'Égypte avait-elle des relations directes avec l'Arabie méridionale avant l'âge des Ptolémées?", Bulletin de l'Institut Français d'Archéologie Orientale, T. 30, pp. 465-75.

Petrie W. Fl. (1918), History of Egypt. Vol. III - From the XIX'th to the XXX' Dynasties, Methuen, London.

Posener G. (1936), La première domination perse en Égypte: recueil d'inscriptions hiéroglyphiques, Imprimerie de l'Institut Français d'Archéologie Orientale, Le Caire.

Rabinowitz I. (1956), "Aramaic Inscriptions of the Fifth Century B.C.E. from a North-Arab Shrine in Egypt", Journal of Near Eastern Studies, Vol. 15, No. 1, pp. 1-9.

Razmjou S. (2002), "Assessing the Damage: Notes on the Life and Demise of the Statue of Darius from Susa", in M. C. Root (ed.), Medes and Persians: Reflections on elusive Empires, Ars Orientalis, Vol. 32, pp. 81-104. 
Canal Stelae of Darius I in the Context of the Imperial Policy of the Achaemenid state

Redford D. B. (1983), "Pithom", in W. Helck and W. Westendorf (eds), Lexikon der Ägyptologie, Bd. IV, Harrassowitz Verlag, Wiesbaden, pp. 1054-8.

Redmount C. A. (1995), The Wadi Tumilat and the Canal of the Pharaohs, Journal of Near Eastern Studies, Vol. 54, No. 2, pp. 127-35.

Root M. C. (1979), The king and kingship in Achaemenid art: essays on the creation of an iconography of empire, Acta Iranica, Troisième série, Textes et mémoires, T. 9, Diffusion, E. J. Brill Orientale, Leiden.

Ryholt K. S. B. (1997), The political situation in Egypt during the second intermediate period, c. 1800-1550 B. C., Museum Tusculanum, København.

Sancisi-Weerdenburg H. (1995), "Darius I and the Persian Empire", in J. M. Sasson (ed.), Civilizations of the Ancient Near East, Vol. II, Charles Scribner's Sons, New York, pp. 1035-050.

Scheil V. (1930), "Inscription de Darius à Suez (menues restitutions)", Bulletin de l'Institut Français d'Archéologie Orientale, T. 30, pp. 293-7.

Spalinger A. (2011), "Königsnovelle and Performance", in V. G. Callender, L. Bareš, M. Bárta, J. Janák, and J. Krejčí (eds), Times, Signs and Pyramids. Studies in Honour of Miroslav Verner on the Occasion of His Seventieth Birthday, Faculty of Arts, Charles University in Prague, Prague, pp. 351-74.

Stanley D. J. and Warne A. G. (1993), "Nile Delta: Recent Geological Evolution and Human Impact”, Science, New Series, Vol. 260, No. 5108, pp. 628-34.

Stevens M. (2020), "Neith as legitimator: Persian religious strategy and Udjahorresnet", Journal of Ancient Egyptian Interconnections, Vol. 26, pp. 185-94.

Tuplin Chr. (1991), "Darius' Suez Canal and Persian Imperialism”, in H. SancisiWeerdenburg and A. Kuhrt (eds), Achaemenid History VI. Asia Minor and Egypt: Old Cultures in a New Empire. Proceedings of the Groningen 1988 Achaemenid History Workshop, Nederlands Instituut voor het Nabue Oosten, Leiden, pp. 237-83.

Uphill E. P. (1988), "An Ancient Egyptian maritime link with Arabia", in Proceedings of the Seminar for Arabian Studies, Vol. 18, Proceedings of the Twenty First Seminar for Arabian Studies held at Durham on 28 $8^{\text {th }}-30^{\text {th }}$ July 1987, Archaeopress, Oxford, pp. 163-70.

Vavroušek P. (2001), "Vojevůdci Dareia I”, in P. Zemánek (ed.), Chatreššar 19992000, Filozofická fakulta Univerzity Karlovy, Praha, pp. 31-46.

Weißbach Fr. H. (1911), Die Keilinschriften der Achaemeniden, J. C. Hinrichs, Leipzig.

Wilson P. (2012), "Waterways, settlements and shifting power in the north-western Nile Delta", Water History, Vol. 4, No. 1, pp. 95-117.

Wolze N. (2019), "Rekonstruktion der Inschriften auf der Kanalstele Darius' I. aus Tell el-Maskhuta", in M. Brose, P. Dils, Fr. Naether, L. Popko, and D. Raue (eds), En détail-Philologie und Archäologie im Diskurs. Festschrift für Hans-W. Fischer-Elfert, De Gruyter, Berlin, pp. 1275-320.

\section{I. А. Семененко \\ “СТЭЛЫ КАНАЛУ” ДАРЫЯ І Ў КАНТЭКСЦЕ ІМПЕРСКАЙ \\ ПАЛІТЫКІ ДЗЯРЖАВЫ АХЕМЕНІДАЎ}

Праўленне Дарыя I было перыядам росквіту імперы Ахеменідаў. Каб аб'яднаць і ўтрымліваць увесь Блізкі Ўсход у межах адзінай дзяржавы, персідскія цары былі вымушаны лічыцца з мясцовымі культурамі і формамі палітычнай арганізацыі і прызнаць, што іх 
I. O. Semenenko

падданыя належаць да розных этнасаў, размаўляюць на розных мовах і вядуць розны лад жыцця. Важнай мэтай было дасягненне інтэграцыі асобных цывілізацыйных цэнтраў у агульную імперскую гандлёва-палітычную сістэму. Адным з самых важных захадаў у гэтым напрамку было пракладанне Дарыем I каналу, які аб'яднаў Ніл і Чырвонае мора. Гэты канал цудоўна ілюструе персідскую палітыку на падначаленых тэрыторыях. Ягонае русла пралягала праз сухі ваді Ўсходняй пустыні і Суэцкага перашыйку, дзе за доўгі час да заснавання дзяржавы Ахеменідаў існавала некалькі водных шляхоў, якія былі створаны фараонамі XXVI, XIX i, магчыма, IX егіпецкімі дынастыямі. Дзейнічаючы ў рамках мясцовых звычаяў і выкарыстоўваючы досвед паспяховага функцыянавання сістэмы кіравання Егіпта, Дарый I, злучыўшы велізарныя рэсурсы сваёй імперыі, упершыню ў гісторыі стварыў 3'яву, якая істотна паўплывала на развіццё рэгіёна Чырвонага мора. У артыкуле ідзе гаворка пра двухмоўныя стэлы, якія ўсталяваны на ўзвышшах уздоўж каналу. Іх клінапісныя i іерагліфічныя тэксты праслаўляюць будаўніцтва канала Дарыем і змяшчаюць яго тытулы, якія напісаны старажытнаегіпецкай, старажытнаперсідскай, вавілонскай і эламскай мовамі. Вывучэнне тэкстаў і мастацкіх матываў, якія намаляваны на стэлах, пралівае святло на працэс пракладання каналу і імперскую палітыку джяржавы Ахеменідаў ў рэгіёне.

Ключавыя словы: Дяржава Ахеменідаў, Дарый I, Канал Фараонаў, Чырвонае мора, старажытнаперсідская мова, клінапіс

\section{I. О. Семененко \\ “СТЕЛИ КАНАЛУ” ДАРІЯ І В КОНТЕКСТІ ІМПЕРСЬКОЇ ПОЛІТИКИ ДЕРЖАВИ АХЕМЕНІДІВ}

Правління Дарія I було періодом розквіту імперії Ахеменідів. Щоб об’єднати та утримувати весь Близький Схід у межах єдиної держави, перські царі були змушені рахуватися 3 місцевими культурами та формами політичної організації і визнати, що їхні піддані належать до різних етносів, розмовляють різними мовами та ведуть різний спосіб життя. Важливою метою було досягнення інтеграції окремих цивілізаційних центрів до загальної імперської торговельно-політичної системи. Одним із найважливіших заходів у цьому напрямку стало прокладення Дарієм I каналу, який з'єднав Ніл із Червоним морем. Цей канал напрочуд вдало ілюструє перську політику на підлеглих територіях. Його русло пролягало через сухі ваді Східної пустелі та Суецького перешийку, де задовго до заснування держави Ахеменідів існувало кілька різних водних шляхів, створених фараонами XXVI, XIX i, можливо, IX єгипетських династій. Діючи в рамках місцевих звичаїв та використовуючи досвід успішного функціонування управлінської системи Єгипту, Дарій I, залучивши величезні ресурси своєї імперії, вперше в історії створив явище, яке суттєво вплинуло на розвиток регіону Червономор'я. У статті йдеться про двомовні стели, встановлені на узвишшях уздовж каналу. Їхні клинописні та ієрогліфічні тексти прославляють будівництво каналу Дарієм і включають його титули, передані давньоєгипетською, давньоперською, вавилонською та еламською мовами. Вивчення текстів та художніх мотивів, зображених на стелах, проливає нове світло на процес прокладання каналу та імперську політику держави Ахеменідів у регіоні.

Ключові слова: Держава Ахеменідів, Дарій I, Канал Фараонів, Червоне море, давньоперська мова, клинопис 